\title{
HAND, EYE, AND FOOT COORDINATION TEST UNTUK MENDETEKSI KEMAMPUAN DASAR LOKOMOTOR
}

\section{HAND, EYE, AND FOOT COORDINATION TEST (HEF) TO DETECT LOCOMOTOR SKILLS}

\author{
Fajar Awang Irawan ${ }^{*}$, Sutaryono ${ }^{2}$, Dhias Fajar Widya Permana ${ }^{3}$, Tafriyadhur Risa \\ Billah4, Mirza Arif Ma'dum5.
}
1,3,4,5Fakultas Ilmu Keolahragaan, Universitas Negeri Semarang, Indonesia ${ }^{2}$ Fakultas Ilmu Pendidikan, Universitas Negeri Semarang, Indonesia

*Corresponding Author: Fajar Awang Irawan , fajarawang@mail.unnes.ac.id

Received: 2021-04-09; Revised: 2021-05-01; Accepted: 2021-05-05

\begin{abstract}
Abstrak
Tujuan dari penelitian ini yaitu untuk merancang instrumen tes gerak lokomotor pada manusia. Penelitian ini merupakan Research and Development (RnD) dengan focus utama untuk mengetahui kemampuan tangan, mata dan kaki (Hand, Eye, and Foot / HEF) yang bermanfaat untuk meningkatkan koordinasi dan menguatkan kemampuan kerja otak serta mampu memberikan manfaat bagi Ilmu Pengetahuan, Kesehatan, dan Teknologi. Total peserta pada uji coba kecil pada penelitian ini berjumlah 10 peserta, dan partisipanpada uji coba lapangan berjumlah 63 peserta. Data pada uji coba lapangan menunjukkan hasil yang signifikan dimana tingkat pemahaman HEF yang didapat sebesar 3.851 (kategori Baik), tingkat kesulitan HEF sebesar 3.965 (kategori Baik), dan manfaat HEF sebesar 3.946 (kategori Baik). Kesimpulan yang didapat dalam penelitian ini yaitu bahwa Hand, Eye, and Foot Coordination Test merupakan instrumen tes yang dapat digunakan untuk mengetahui pergerakan lokomotor pada manusia. Penelitian selanjutnya diharapkan dapat mengembangkan produk tes lokomotor dengan menggunakan sistem digitalisasi yang lebih sederhana.
\end{abstract}

Kata Kunci: tes koordinasi, lokomotor, kemampuan gerak

\begin{abstract}
The purpose of this study was to design a test instrument for locomotor movement in humans. This development research ( $R$ and $D$ ) has the intention to determine the ability of the hands, eyes and feet (Hand, eye, and foot / HEF) with the benefits for coordination and improving brain work and is able to provide benefits to Science and Technology. The total participants in the small trial was 10 participants, and 63 participants in the field trial. The data in the field test showed significant results which was the level of understanding of HEF was 3,851 (Good category), the difficulty level of HEF was 3,965 (Good category), and the benefits of HEF was 3,946 (Good category). The conclusion found that the Hand, Eye, and Foot Coordination Test is a test instrument that can be used to determine locomotor movements in humans. Future research can develop locomotor test products with digitalize system.
\end{abstract}

Keywords: coordination test, locomotor, movement skills

How To Cite: Irawan, F. A., Sutaryono., Permana, D.F.W., Billah, T.R., Ma'dum. M.A. (2021). Hand, eye, and foot coordination test untuk mendeteksi kemampuan dasar lokomotor. Journal of Sport Education (JOPE), 3 (2), 8592. doi: http://dx.doi.org/10.31258/jope.3.2. 85-92

Journal of Sport Education (JOPE) is an open access article under the CC-BY-SA 4.0

\section{PENDAHULUAN}

Seseorang yang bergerak menggunakan lebih dari satu bagian tubuh pasti memiliki koordinasi yang baik terutama dalam berpikir menggunakan otak kanan dan kiri. Pada kenyataanya, koordinasi sulit dipisahkan dengan kelincahan sehingga terkadang tes 
koordinasi juga bertujuan untuk mengukur kelincahan. Koordinasi merupakan gabungan dari beberapa otot secara tepat dan seimbang menjadi satu pola gerak. Koordinasi yang baik akan mampu menggabungkan beberapa gerakan tanpa penekanan dalam rangkaian yang benar dan menampilkan gerakan yang kompleks dengan lancar tanpa mengeluarkan energi yang berlebihan.

Koordinasi juga merupakan alat yang digunakan untuk mengetahui kemampuan seseorang dalam merangkai beberapa unsur gerak menjadi suatu gerakan yang selaras dengan tujuannya. Kemampuan ini pada runtutannya juga memberikan tugas kinerja yang fleksibel dan akurat yang seringkali melibatkan perasaan dan rangkaian koordinasi otot yang mempengaruhi gerakan (Irawan, Chuang, \& Peng, 2017; Irawan \& Long-Ren, 2015a, 2015b). Begitu pula pada salah satu gerakan menembak (Irawan, Permana, Akromawati, \& Yang-tian, 2019; Purnomo \& Irawan, 2021) yang memfokuskan pada koordinasi mata tangan untuk akurasi dalam shooting pada cabang olahraga petanque dan sepakbola. Sedangkan pada Anam, Irawan, \& Nurrachmad, (2018) membahas tentang koordinasi mata-kaki untuk akurasi tembakan dalam sepak bola. Sehingga, dapat diartikan bahwa setiap bagian dari tubuh manusia memiliki peran penting dalam memberikan kontribusi pada gerakan-gerakan lainnya. Secara umum, koordinasi adalah kemampuan seseorang untuk mengkoordinasikan mata, tangan, dan kaki menjadi rangkaian gerakan yang lengkap, komprehensif, dan berkesinambungan secara cepat dan tepat dalam ritme yang terkontrol dan efektif.

Koordinasi merupakan bagian dari komponen kondisi fisik (Fadli \& Sutysna, 2017) selain kecepatan, kekuatan, daya tahan, kelenturan, keseimbangan dan ritme yang berperan dan berpadu dalam suatu gerakan. Salah satu elemen yang tidak tampak atau kurang berkembang secara otomatis akan mempengaruhi kesempurnaan koordinasi gerakan yang dimiliki. Sebagai contoh saat di lapangan ketika seseorang mencoba melakukan aktivitas fisik dengan melakukan koordinasi antara ekstremitas atas dan ekstrimitas bawah. Saat seseorang sedang beraktivitas fisik dengan bermain maka ada rangkaian gerak yang dilakukan seperti melompat menggunakan kedua kaki, ada juga selain melompat menggunakan kedua kaki dengan cara memvariasikan gerakan telapak tangan dan susunan telapak kaki secara bersamaan saat melakukan lompatan. Kesulitan yang dialami seseorang dalam melakukan gerakan koordinasi karena memang integrasi antara satu organ dengan organ lainnya sangat erat kaitannya. Dari berbagai penjelasan di atas dapat ditegaskan bahwa koordinasi adalah kemampuan seseorang dalam merangkai berbagai gerakan menjadi satu kesatuan dengan gerakan yang selaras dan sesuai dengan tujuan yang diharapkan.

Hal ini akan semakin menarik jika sebuah permainan dapat diintegrasikan dengan menggabungkan tes koordinasi antara tangan, mata, dan kaki. Tes koordinasi mata-tangan dan mata-kaki (Anam et al., 2018) sudah sering dikenal dan menjadi acuan untuk tes koordinasi dalam olahraga. Kemampuan otak kanan dan kiri digunakan untuk mengontrol gerakan antara kaki dan tangan secara bersamaan dengan melalui penglihatan dan konsentrasi (Irawan, Permana, et al., 2019) dalam aktivitas fisik. Berdasarkan uraian di atas, maka penulis tertarik untuk merancang suatu media untuk gerak lokomotor pada manusia, sehingga nantinya setiap orang dapat belajar untuk dapat memiliki keterampilan dalam menggunakan 3 organ (mata, tangan, dan kaki) sekaligus dengan pengendalian gerakan yang mereka lakukan.

Pemanfaatan ilmu pengetahuan dan teknologi yang tepat diharapkan mampu menyelesaikan permasalahan yang berkaitan dengan ilmu di bidang olahraga yang menunjang kemajuan suatu bidang khususnya bidang olahraga dan kesehatan. Keterbatasan peralatan penunjang merupakan salah satu faktor yang dapat menghambat kemajuan dan pelayanan yang diberikan, baik dari segi informasi, pengetahuan, pembelajaran, pelatihan maupun praktek langsung di lapangan. Panduan tes dan pengukuran pada koordinasi utamanya pada tangan, mata dan kaki untuk gerakan lokomotor diperlukan sebagai acuan 
dalam tes. Tes koordinasi ini nantinya diperlukan untuk memudahkan dalam menilai hubungan antar bagian tubuh saat bekerja untuk meningkatkan kinerja. Tujuan penelitian ini adalah merancang instrumen tes gerak lokomotor pada manusia. Selain itu, penelitian ini juga untuk mengetahui pelaksanaan tes koordinasi tangan, mata dan kaki pada gerak lokomotor dalam satu kali tes.

\section{METODE}

Dalam penelitian ini penulis menggunakan metode penelitian pengembangan (Research and Development) sebagai metode dalam penelitian. Penelitian pengembangan yang dilakukan ini bertujuan untuk menghasilkan suatu produk berupa alat untuk mengetahui kemampuan tangan, mata dan kaki (Hand, eye, and foot / HEF) yang bermanfaat untuk koordinasi dan meningkatkan kerja otak serta mampu untuk memberikan manfaat bagi Ilmu Pengetahuan dan Teknologi. Total peserta yang mengikuti uji coba kecil sebanyak 10 peserta, dan uji coba lapangan berjumlah 63 peserta.

Informed consent juga disiapkan sebagai syarat dalam penelitian bahwa peserta secara resmi mengikuti penelitian dengan kesadaran dan bertanggung jawab atas apa yang dilakukan selama penelitian berlangsung. Penelitian ini juga telah lolos dari Komisi Etik Riset Kesehatan Universitas Negeri Semarang dengan Nomor 073 / KPEK / EC / 2020 sesuai dengan Standards and Operational Guidance untuk Ethics Review pada kesehatan terkait penelitian pada peserta yang diikuti oleh manusia sebagai sampel pada penelitian terkait. Sehingga sesuai dengan prosedur pelaksanaan dan menjamin keselamatan peserta dan penelitian yang dilakukan.

Terdapat 7 langkah yang digunakan dalam penelitian ini sesuai dengan petunjuk dari Irawan \& Pangesti, (2020); Sutaryono, Ansori, Irawan, \& Permana, (2020); Sutaryono, Irawan, \& Permana, (2020), yaitu: 1) Melakukan penelitian pendahuluan dan pengumpulan informasi meliputi obsersvasi lapangan dan tinjauan pustaka, 2) Mengembangkan bentuk produk awal dalam blue print (prototype), 3) Evaluasi dari ahli tes dan pengukuran, serta biomekanik, kemudian diuji dalam kelompok kecil, 4) Revisi produk pertama dilakukan berdasarkan revisi produk hasil evaluasi ahli dan uji coba kelompok kecil. Revisi ini digunakan untuk menyempurnakan produk awal yang dibuat peneliti, 5) Uji coba lapangan, 6) Revisi produk akhir yang dilakukan berdasarkan hasil uji coba lapangan, dan 7) Hasil akhir berupa produk, yaitu alat tes dan pengukuran untuk menguji koordinasi gerak lokomotor.

Instrumen yang digunakan untuk mengumpulkan data dalam penelitian ini berupa lembar evaluasi dan angket. Lembar evaluasi digunakan untuk mengumpulkan data dari ahli tes dan pengukuran serta ahli biomekanika. Validator dalam penelitian ini memiliki kontribusi yang sangat besar untuk menentukan kelayakan kualitas produk yang dihasilkan. Alasan pemilihan kuesioner sebagai instrumen penelitian untuk mengetahui seberapa besar manfaat produk yang dihasilkan oleh pengguna serta hasil penggunaan media produk Tes Koordinasi Tangan, Mata, dan Kaki untuk pergerakan lokomotor. Kuesioner nantinya akan diberikan kepada para ahli dan juga kepada peserta. Angket ahli difokuskan pada model tes koordinasi dan petunjuk pelaksanaan tes yang dilakukan, sedangkan angket untuk peserta difokuskan untuk mengetahui apakah instrumen tes koordinasi ini mudah dan tepat digunakan untuk mendeteksi gerakan lokomotor. Kuesioner untuk ahli berisi pertanyaanpertanyaan yang mencakup beberapa aspek terkait dengan penggunaan produk Tes Koordinasi Tangan, Mata, dan Kaki.

Faktor yang digunakan dalam kuesioner adalah kejelasan dan penggunaan produk yang dikembangkan. Komentar dan saran yang digunakan untuk meningkatkan produk yang digunakan. Rentang evaluasi mengacu pada skala likert (Irawan \& Permana, 2020; Irawan, Setiowati, Permana, \& Sandiyudha, 2019) dimana pilihan jawaban mulai dari "Sangat Tidak Layak" hingga "Sangat Layak" dengan memberi tanda cek list " $\sqrt{ }$ " pada kolom yang tersedia. 


\section{HASIL}

Data pada hasil uji coba kecil dan uji lapangan pada Hand, Eye, and Foot Coordination (HEF) dimana uji coba kecil menggunakan 10 partisipan dan untuk uji lapangan menggunakan 65 partisipan. Dalam menggambil data partisipan yang sudah berpartisipasi dal uji coba kecil tidak diperkenankan untuk menjadi partisipan dalam uji lapangan karena akan mengintervensi dan menggangu data dalam penelitian.

Hasil uji coba kecil pada materi pemahaman HEF mendapatkan 3.2 dengan kriteria Cukup Baik. Tingkat kesulitan HEF didapatkan 3.3 dan berada pada kategori Cukup Baik. Sedangkan keuntungan dari HEF dalam gerak lokomotor didapatkan 3.34 yang berada pada kategori Cukup Baik pula. Data pada uji lapangan menunjukkan hasil yang signifikan dimana tingkat pemahaman HEF berapa pada kategori Baik sebesar 3.851, sedangkan tingkat kesulitan HEF sebesar 3.965 pada kategori Baik. Keunggulan HEF dalam penelitian ini didapatkan data sebesar 1.96 pada kategori Baik.

Data Hand, Eye, and Foot Coordination Test ditunjukkan pada diagram prosentase yang ada pada gambar 1 untuk mengetahui seberapa besar angka yang didapatkan pada data penelitian melalui responden dalam penelitian ini.

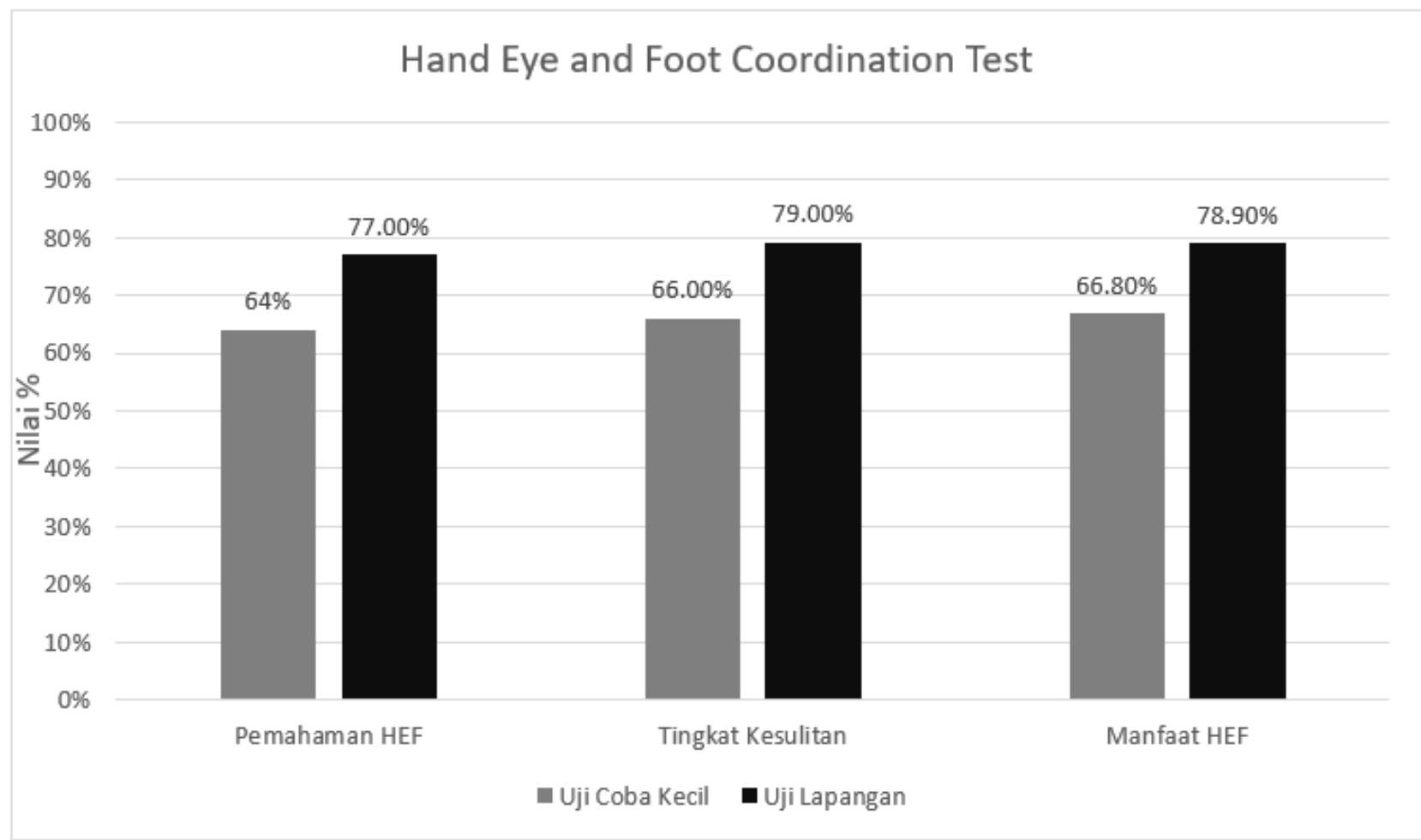

Gambar 1. Hasil Uji Coba Kecil dan Uji Lapangan

Data yang ditunjukkan pada tampilan gambar 1 menunjukkan perbedaan antara uji coba kecil dan uji pangan berdasarkan pemahaman HEF, tingkat kesulitan HEF, dan keuntungan dari HEF. Data penelitian pada uji coba kecil menunjukkan data pemahaman HEF sebesar 64\% dengan kategori Cukup Bagus. Selain ituuntuk uji lapangan didapatkan hasil 77\% pada kategori baik untuk tingkat kesulitan HEF pada uji coba kecil sebesar 66\% pada kategori Memuaskan sedangkan untuk uji lapangan data yang didapatkan sebesar $66.8 \%$ pada kategori cukup baik. Data untuk keuntungan pada penelitian HEF pada uji lapangan menunjukkan 79\% pada category Baik.

\section{PEMBAHASAN}

Berdasarkan hasil penelitian yang telah didapatkan, tes HEF ini juga memiliki tujuan 
untuk meningkatkan kemampuan gerak manusia sehingga jika tes ini ditujukan untuk anak maka akan lebih bermanfaat dalam tumbuh kembang anak terutama dalam gerak lokomotor seperti dalam penelitian Gallahue \& Donnelly, (2003); Saputra \& Firdaus, (2019) yang membahas tentang gerak lokomotor sebagai dasar dalam mengetahui keterampilan gerak dan koordinasi yang dimiliki. Alat test ini baik digunakan untuk menunjang bagaimana pergerakan kemampuan lokomotor yang akan berguna dikemudian hari. Gerakan lokomotor merupakan salah satu gerakan penting yang harus diperhatikan karena gerakan ini merupakan komponen dasar dalam melakukan gerakan selanjutnya. HEF diharapkan mampu menjadi salah satu alat berbasis teknologi pada era 4.0 dan mampu diterapkan untuk kemudian mampu mendeteksi kemampuan gerak yang akan dihubungkan dengan olahraga yang sesuai dengan kemampuan lokomotor yang dimiliki. Sehingga kemajuan olahraga mampu dideteksi berdasarkan kinerja lokomotor yang dominasi pada anak.

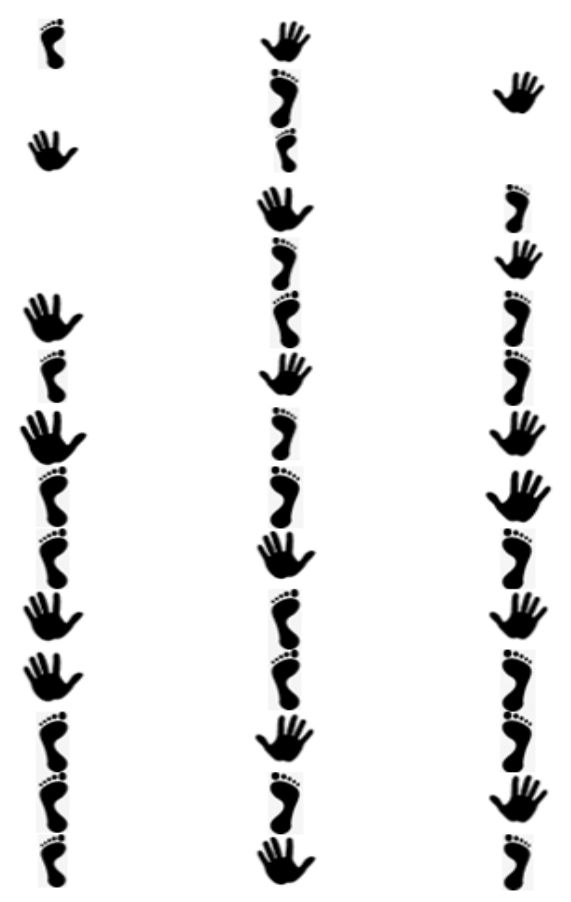

Gambar 2. Model rangkaian dalam Hand, Eye, and Foot Coordinataion test

Gambar 2 merupakan model dari tes HEF yang direpresentasi menggunakan model gambar rangkaian telapak tangan dan telapak kaki. Prosedur pelaksanaan dari setiap partisipan diberikan kesempatan untuk menempatkan telapak kaki dan telapak tangan sesuai dengan gambar yang dipasang di lantai. Pada setiap posisi rangkaian gambar, partisipan hanya diberikan dua detik dan harus segera berpindah ke tahap selanjutnya. Partisipan dinyatakan gagal jika salah menempatkan posisi kaki dan atau tangannya pada gambar yang disediakan. Selain itu, jika peserta melebihi batas waktu 2 detik yang disediakan dalam menginjak atau meletakkan telapak tangan juga dianggap gagal. Oleh karena itu, tes HEF ini diharapkan dapat meningkatkan gerak refleks pada setiap rangkaian gerak olahraga ataupun aktivitas fisik yang dilakukan setiap harinya dan juga untuk mengukur kemampuan koordinasi antara mata, tangan dan kaki secara bersama dalam satu waktu.

Fisher et al., (2005) mengungkapkan bahwa keterampilan gerak dasar dan kebiasaan dalam aktivitas fisik pada anak perlu dibiasakan untuk bergerak agar dapat merespon saraf dan otot dengan lebih cepat. Tes HEF ini juga memiliki tujuan untuk meningkatkan mobilitas gerak manusia sehingga jika tes ini digunakan untuk anak anak akan lebih bermanfaat dalam perkembangan dan pertumbuhannya. Khususnya pada gerak lokomotor. Penelitian lain yang 
dilakukan oleh Goodway, Crowe, \& Ward, (2003) menegaskan bahwa pengaruh pembelajaran pada keterampilan gerak dalam pengembangan gerak motoric memberikan kontribusi yang baik dalam pengembangan dan penyempurnaan motorik dasar khususnya gerak lokomotor.

Perlunya bimbingan dan arahan mengenai informasi dan referensi keterampilan gerak lokomotor diperlukan untuk melatih stimulasi dan membiasakan seseorang untuk melakukan otomatisasi gerak. Gerakan yang sering dilakukan akan menjadi kebiasaan dalam kehidupan sehari-hari dan sangat berguna khususnya dalam aktivitas fisik dan latihan dalam olahraga. Pengembangan dasar keterampilan gerak untuk anak (Rismayanthi, 2013) merupakan dasar untuk melengkapi tingkatan keterampilan dari kemampuan dalam pembelajaran gerak lokomotor dan non-lokomotor.

Hal ini juga dapat dilakukan dengan teknik sederhana seperti kombinasi dasar berjalan, berlari, melompat, dan melempar (Wulansari, 2019) melalui olahraga dan aktivitas fisik. Pada tahap selanjutnya yaitu penerapan gerak lokomotor menjadi dasar penyempurnaan gerakan selanjutnya dalam gerakan variasi yang digunakan pada beberapa pertandingan. Kemampuan ini menjadi pilihan yang baik untuk merangsang dan mengembangkan keterampilan gerak lokomotor pada anak (Septi, 2015).

Lebih lanjut dijelaskan bahwa gerakan lokomotor memiliki hubungan erat dengan pembelajaran olahraga dikarenakan gerakan ini meliputi rangkaian gerak lari cepat, lompat jauh, loncat tinggi dan gerakan variasi yang ada pada setiap cabang olahraga (Saputra \& Firdaus, 2019). Oktarifaldi, Syahputra, \& Putri, (2019) mengungkapkan tentang perlunya mengembangkan media untuk mendetekesi kemampuan gerak lokomotor terutama pada anak. Lebih lanjut dijelaskan bahwa gerakan lokomotor erat kaitannya dengan pembelajaran Pendidikan jasmani di sekolah dan guru penjas memiliki peran penting dalam mengembangkan serta melatih kemampuan lokomotor anak ke tahap yang lebih spesifik.

Humaedi \& Abduh, (2019) mengungkapkan bahwa keterampilan motorik terdiri dari tiga kategori yaitu; lokomotor, non-lokomotor, dan gerak manipulatif. Pemain yang memiliki kemampuan motorik yang baik akan lebih mudah dan cepat mengembangkannya untuk menguasai teknik dasar bermain bola.

Boguszewski, Buda, Adamczyk, \& Białoszewski, (2017) dalam penelitiannya mengungkapkan jika atlet yang memiliki prestasi baik memiliki kemampuan lokomotor skill yang baik. Penentuan kemampuan lokomotor dapat dijadikan sebagai indikasi untuk mengidentifikasi atlet yang akan cemerlang dimasa depan. Memahami serta dapat mendeteksi kemampuan dan karakteristik lokomotor (Emmonds et al., 2020) dalam keperluan kompetisi dapat membantu pelatih untuk mengoptimalkan program pelatihan pada atlet ditingkat Internasional. Penelitian ini dalam penerapannya perlu dikembangkan dan disosialisasikan untuk mendeteksi gerak lokomotor pada manusia, sehingga nantinya seorang atlet tidak akan mengalami gangguan dalam melakukan koordinasi gerak. Keterbatasan dalam penelitian ini yaitu media yang digunakan masih berupa gambar stiker yang di pasang dilantai sehingga perlu adanya penyempurnaan dalam menggunakan matras bergambar ataupun media yang lebih sederhana dalam pemasangan dan penyimpanannya.

\section{SIMPULAN}

Kesimpulan dalam penelitian ini yaitu tes HEF merupakan instrumen tes yang dapat digunakan untuk mengetahui gerakan lokomotor pada manusia. Pelaksanaan tes koordinasi gerakan tangan, mata dan kaki pada lokomotor dengan menggunakan Tes HEF termasuk dalam kategori Baik dimana pemahaman HEF sebesar 77\% pada kategori Baik, Tingkat Kesulitan HEF sebesar 79\% pada kategori Baik, dan Manfaat dari HEF sebesar 78\% dalam kategori Baik. Perlu adanya perancangan berbasis sederhana dan permanen untuk digunakan sebagai media dalam aplikasi dan pengukuran Koordinasi HEF karena akan lebih efektif dalam pelaksanaan tes yang dilakukan. 


\section{DAFTAR PUSTAKA}

Anam, K., Irawan, F. A., \& Nurrachmad, L. (2018). Pengaruh Metode Latihan dan Koordinasi Mata-Kaki terhadap Ketepatan Tendangan Jarak Jauh. Jurnal Media Ilmu Keolahragaan Indonesia, 8(2), 57-62.

Boguszewski, D., Buda, M., Adamczyk, J. G., \& Białoszewski, D. (2017). Relationship Between Functional Limitations of the Locomotor System and Performance in Judo. Polish Journal of Sport and Tourism, 24(3), 145-149. http://doi.org/10.1515/pjst-2017-0015

Emmonds, S., Weaving, D., Dalton-Barron, N., Rennie, G., Hunwicks, R., Tee, J., ... Jones, B. (2020). Locomotor characteristics of the women's inaugural super league competition and the rugby league world cup. Journal of Sports Sciences, 00(00), 1-8. http://doi.org/10.1080/02640414.2020.1790815

Fadli, M., \& Sutysna, H. (2017). Gambaran Nilai Kapasitas Vital Paru dan Tingkat Kebugaran pada Mahasiswa Perokok dan Bukan Perokok. Jurnal Kesehatan Andalas, 2(3), 153-158.

Fisher, A., Reilly, J. J., Kelly, L. A., Montgomery, C., Williamson, A., Paton, J. Y., \& Grant, S. (2005). Fundamental Movement Skills and Habitual Physical Activity in Young Children. Med Sci Sports Exerc, 37(4), 684-688.

Gallahue, D. L., \& Donnelly, F. C. (2003). Development Physical Education for All Children (4th ed.). HUMAN KINETICS PUBLISHERS, INC.

Goodway, J. D., Crowe, H., \& Ward, P. (2003). Effects of Motor Skill Instruction on Fundamental Motor Skill Development. Adapted Physical Activity Quarterly, 20(1), 298-314.

Humaedi, \& Abduh, I. (2019). Hubungan Motor Ability dengan Keterampilan Bermain Sepak Bola Mahasiswa PJKR UNTAD. Jurnal Kreatif, 7(4), 101-111.

Irawan, F. A., Chuang, L.-R., \& Peng, H. (2017). Kinematic Comparison of Upper Extremity Among Fastball , Curveball, and Slider in Taiwan College Pitchers. Chinese Journal of Sport Biomechanics, 14(1), 1-8.

Irawan, F. A., \& Long-Ren, C. (2015a). Comprehensive Pitching Biomechanics and Injury Prevention for Young Baseball Pitchers-A review. Journal of Physical Education and Sport Science, 21, 11-21.

Irawan, F. A., \& Long-Ren, C. (2015b). Pitching Biomechanics and Injury Prevention to Improving Performance for Young Baseball Pitchers - A review. In 1st UNNES International Conference on Research Innovation \& COmmercialization for Better Life.

Irawan, F. A., \& Pangesti, O. P. D. A. (2020). Bokavia Sebagai Alternatif Media Pembelajaran Pada Olahraga Petanque. Media Ilmu Keolahragaan Indonesia, 10(1), 23-27. http://doi.org/10.15294/miki.v10i1.21368

Irawan, F. A., \& Permana, D. F. W. (2020). Parent-Child Fun Games sebagai Upaya Meminimalisasi Smartphone Addiction pada Anak di Madrasah Ibtidaiyah. Jurnal Pemberdayaan Masyarakat Mandiri Indonesia, 1(1), 1-8. 
Journal of Sport Education (JOPE), 3 (2) 2021 - 92

Fajar Awang Irawan ${ }^{1 *}$, Sutaryono², Dhias Fajar Widya Permana ${ }^{3}$, Tafriyadhur Risa Billah ${ }^{4}$, Mirza Arif Ma'dum

Irawan, F. A., Permana, D. F. W., Akromawati, H. R., \& Yang-tian, H. (2019). Biomechanical Analysis of Concentration and Coordination on The Accuracy in Petanque Shooting. Journal of Physical Education, Sport, Health and Recreations, 8(2), 96-100.

Irawan, F. A., Setiowati, A., Permana, D. F. W., \& Sandiyudha, T. B. (2019). Augment Reality Human Anatomy ( ARMY) as Learning Media in Sport Science. In 5th International Conference on Physical Education, Sport, and Health (Vol. 362, pp. 46-49). Retrieved from https://ejournal.ressi.id/index.php/sepakbola/article/view/90/61

Oktarifaldi, Syahputra, R., \& Putri, L. P. (2019). Pengaruh Kelincahan, Koordinasi Dan Keseimbangan Terhadap Kemampuan Lokomotor Siswa Usia 7 Sampai 10 Tahun. Jurnal MensSana, 4(2), 190. http://doi.org/10.24036/jm.v4i2.117

Purnomo, A., \& Irawan, F. A. (2021). Analisis Kecepatan Dan Kelincahan Dalam Menggiring Bola Pada Tim Futsal. Sepakbola, 1(1), 1-7.

Rismayanthi, C. (2013). Mengembangkan Keterampilan Gerak Dasar Sebagai Stimulasi Motorik Bagi Anak Taman Kanak-Kanak Melalui Aktivitas Jasmani. Jurnal Pendidikan Jasmani Indonesia, 9(1), 64-72.

Saputra, M. W., \& Firdaus, K. (2019). Hubungan Keterampilan Gerak Dasar Lokomotor dengan Hasil Belajar Penjasorkes. Jurnal Pendidikan Olahraga, 2(8), 14-20.

Sutaryono, Ansori, I., Irawan, F. A., \& Permana, D. F. W. (2020). Development of Bakiak Football (Bakfoot) as Alternative Games for Elementary School. In Development of Bakiak Football (Bakfoot) as Alternative Games for Elementary School - ICSS 2019 (pp. 10-14). http://doi.org/10.4108/eai.5-11-2019.2292524

Sutaryono, Irawan, F. A., \& Permana, D. F. W. (2020). Multicolor Flag game (MFG) as an Alternative Learning Method for Adaptive Students. Malaysian Journal of Movement, Health, 9(1), 187-193.

Wulansari, S. (2019). Meningkatkan Kemampuan Menerapkan Prosedur kombinasi Gerak Dasar Jalan, Lari, Lompat dan Lempar Dengan Permainan Olahraga Yang Dimodifikasi Dengan Olahraga Tradisional. Jurnal Ilmiah Pendidikan Agama Islam, 3(1), 77-92. 